\title{
COBIB.SI: prirast bibliografskih zapisov v letu 2018
}

\author{
COBIB.SI: increment of bibliographic records in 2018
}

\section{Ema Dornik $^{1}$}

IZVLEČEK: V članku je predstavljena analiza prirasta bibliografskih zapisov v COBIB.SI v letu 2018. V analizo smo vključili podatke, zbrane tekom leta. Poudarek je na bibliografskih podatkih $(n=169.226)$, predstavljeni so tudi podatki o prirastu normativnih zapisov za osebna imena v bazi CONOR.SI $(n=$ 63.716) in podatki o prevzetih zapisih iz drugih baz podatkov, kot so: WorldCat (OCLC), Register ISSN (International Standard Serial Number), Online katalog Kongresne knjižnice ter Library of Congress Name Authority File (LCNAF). Predstavljena je analiza prirasta bibliografskih zapisov po posameznih mesecih leta 2018 in najproduktivnejši dnevi tega leta. $V$ zadnjem kvartalu leta je bilo kreiranih največ $(29,4 \%)$ bibliografskih zapisov, in sicer največ $(n=1.060)$ v četrtek, 6. decembra 2018. Največ zapisov glede na dan $v$ tednu je bilo kreiranih ob torkih. Po tipu zapisov se nadaljuje večletni trend: največ jih je bilo kreiranih za monografske publikacije $(50,2 \%)$ in sestavne dele $(38,7 \%)$. Najmanj zapisov je bilo kreiranih v februarju in avgustu. V letu 2018 so zapise prispevali katalogizatorji s 583 uporabniškimi imeni iz 258 knjižnic. S predstavitvijo prirasta bibliografskih zapisov v COBIB.SI želimo prikazati obseg dela in hkrati izpostaviti pomembnost katalogizatorjevega dela v sistemu COBISS.

KLJUČNE BESEDE: bibliografske baze podatkov, COBIB.SI, katalogizacija, letni prirast

ABSTRACT: The article presents the analysis of the annual increment of bibliographic records in COBIB.SI in 2018. The analysis includes data gathered throughout the year. The emphasis lies on bibliographic data $(n=169,226)$, but also includes data on the increment of authority records for personal names in the CONOR.SI database $(n=63,716)$ and data on records downloaded from other databases, such as WorldCat (OCLC), ISSN Register (International Standard Serial Number), Library of Congress Online Catalog and the Library of Congress Name Authority File (LCNAF). Included is the analysis of the increment of bibliographic records by months for 2018 and the most productive days of the year. In the last quarter of the year, the most $(29.4 \%)$ records were created; the most $(n=1,060)$ on Thursday, 6 December 2018. The most productive day of the week based on the number of created records is Tuesday. In terms of record type, the trend of the following years continues, as the most records were created for monographs (50.2\%) and component parts (38.7\%). The least records were created in February and August. In 2018, cataloguers with 583 usernames from 258 libraries contributed records. Through the presentation of the increment of bibliographic records in COBIB.SI, we would like to present the scope and emphasise the importance of a cataloguer's work within the COBISS system.

KEYWORDS: bibliographic databases, COBIB.SI, cataloguing, annual increment

\section{Uvod}

COBISS.net (Kooperativni online bibliografski sistem in servisi) je sodobno zasnovana informacijska mreža, ki v državah Jugovzhodne Evrope deluje kot katalizator prenove teh družb in kot infrastruktura za izmenjavo informacij o intelektualni produkciji, s tem pa tudi kot spodbujevalec medkulturnega dialoga v regiji (IZUM, 2019). V mreži COBISS.net sodeluje 1.347 knjižnic (podatek na dan 11. 6. 2019) iz sedmih držav (v abecednem vrstnem redu: Albanija,

\footnotetext{
${ }^{1}$ Doc. dr. Ema Dornik, bibliotekarska višja svetnica, Institut informacijskih znanosti (IZUM), Maribor, Slovenija, ema.dornik@izum.si.
} 
Bolgarija, Bosna in Hercegovina, Črna gora, Makedonija, Slovenija in Srbija) (COBISS.net, 2019; COBISS.net v številkah, 2019).

V Sloveniji je na dan 31. 12. 2018 sodelovalo 910 polnopravnih članic, ki jih delimo po tipih knjižnic: Narodna in univerzitetna knjižnica, 83 univerzitetnih in visokošolskih knjižnic, 131 specialnih, 61 splošnih in 634 šolskih knjižnic (IZUM, 2019). Gre za nacionalni knjižnični informacijski sistem z vzajemno katalogizacijo, vzajemno bibliografsko-kataložno bazo podatkov COBIB.SI in lokalnimi bazami podatkov sodelujočih knjižnic, bazo podatkov o knjižnicah COLIB.SI, normativno bazo podatkov CONOR.SI ter s številnimi drugimi funkcijami (Organizacijski model sistema COBISS, 2018).

Vzajemna katalogizacija omogoča racionalno delitev dela in prihranek pri zahtevnem postopku obdelave knjižničnega gradiva in vodenju katalogov. Za vsako enoto zadošča samo ena obdelava, nato je zapis prek vzajemne bibliografsko-kataložne baze podatkov COBIB dostopen vsem udeležencem $v$ sistemu in $v$ mreži COBISS.net (Vzajemna katalogizacija (COBISS3/Katalogizacija), 2018). V Sloveniji ima aktivno dovoljenje za vzajemno katalogizacijo monografskih publikacij 681 oseb, v vzajemni katalogizaciji pa sodeluje 299 knjižnic (COBISS3 - Knjižnice, 2019). Katalogizatorji pri svojem delu poleg bibliografske baze dopolnjujejo tudi normativno bazo osebnih imen in tako pri svojem delu povezujejo bibliografske zapise z normativnimi zapisi. Sredi leta 2018 je bil v lokalnih bazah COBIB.SI kreiran 15-milijonti zapis. V sistemu vzajemne katalogizacije je bilo v letu 2018 v bazi glede na tip zapisa 50,2 \% zapisov za monografske publikacije, 38,7 \% za sestavne dele, 7,7 \% za izvedena dela (dogodke), 2,9\% za serijske publikacije, 0,3 \% za zbirne zapise in 0,1 \% zapisov za integrirne vire. $V$ tem letu je bilo izbrisanih 2.011 zapisov (Bibliografske baze podatkov in podatki o zalogi, 2019).

S predstavitvijo prirasta bibliografskih zapisov v COBIB.SI želimo odgovoriti na vprašanje, koliko zapisov katalogizatorji kreirajo na letni ravni. Prav tako želimo prikazati obseg in izpostaviti pomembnost katalogizatorjevega dela $v$ sistemu COBISS ter vključiti prikaz petletnega spremljanja prirasta COBIB.SI.

\section{Metodologija}

Vir podatkov je vzajemna baza COBIB.SI, v kateri s pregledom pojmov za iskalno predpono za datum kreiranja/prevzema $(\mathrm{dm}=)$ poiščemo podatke za pretekli mesec, npr. $\mathrm{dm}=201801+$ pregled pojmov. Podatke zbiramo skozi vse leto, in sicer na začetku meseca za pretekli mesec. Vzajemna baza se dnevno spreminja, zato številke, predstavljene $v$ članku, ne kažejo trenutnega stanja podatkov $v$ bazi. Iz zajema podatkov so izvzeti bibliografski zapisi, ki so bili v vzajemni katalog shranjeni programsko (npr. Elinks, $n=3.672$ ), ter lokalni zapisi, ki so bili shranjeni v vzajemno bazo.

Vključeni so kreirani in prevzeti bibliografski zapisi, ki so jih v vzajemni katalog prispevali katalogizatorji. Vključeni so vsi dnevi v letu, saj se COBIB.SI ves čas spreminja in dopolnjuje. Za delovne dni smo šteli vse dni od ponedeljka do petka, za dela proste dni smo upoštevali sobote, nedelje in praznike.

Zbrani podatki so predstavljeni bodisi na letni bodisi na mesečni ravni. $V$ analizo podatkov za leto 2018 smo vključili 169.226 bibliografskih zapisov. Na slikah so podatki predstavljeni po datumih, v tabelah so prazniki prikazani ločeno od preostalih dni. Ob slikah so zabeleženi dnevi zajema podatkov, veljajo pa tudi za podatke, predstavljene $v$ tabelah mesečnih prirastov. 


\section{Analiza prirasta bibliografskih zapisov}

Baze podatkov vsebujejo bibliografske zapise za različne vrste gradiva (monografske publikacije, serijske publikacije, integrirne vire, članke in druge sestavne dele), za potrebe vodenja osebnih bibliografij avtorjev pa tudi zapise za izvedena dela. Konec leta 2018 (podatki na dan 31. 12. 2018) je bilo v vzajemni bazi podatkov COBIB.SI skupaj 5.253 .480 bibliografskih zapisov (od tega 1.775 .699 z vsaj enim avtorjem s šifro raziskovalca). V letu 2018 so katalogizatorji s 583 različnimi uporabniškimi imeni iz 258 knjižnic (originalno) kreirali 153.660 bibliografskih zapisov. Iz mreže COBISS.net je bilo prevzetih 2.499 zapisov, iz baze WorldCat (OCLC) 10.080, iz Registra ISSN 4.414 zapisov (od tega 3.672 ob ažuriranju baze podatkov ELINKS.SI), iz Online kataloga Kongresne knjižnice (LC) pa 1.894 zapisov. Največja dodana vrednost zasnove vzajemnega kataloga je kooperativno sodelovanje pri kreiranju bibliografskih zapisov (Bibliografske baze podatkov in podatki o zalogi, 2019).

\subsection{Letni prirast}

V letu 2018 je bilo največ zapisov kreiranih v zadnji četrtini leta ( $Q 4=29,4 \%$ ). V prvi četrtini leta (Q1) je bilo kreiranih 23,9\%, v drugi (Q2) 22,9\%, v tretji (Q3) pa 23,8 \% letnega prirasta.

Pregled prirasta bibliografskih zapisov po mesecih leta 2018 (padajoče glede na število kreiranih zapisov) prikazuje tabeli 1.

Tabela 1: Mesečni prirast bibliografskih zapisov COBIB.SI v letu 2018 (padajoče po mesecih glede na število kreiranih zapisov)

\begin{tabular}{lll}
\hline Mesec & Kreirani zapisi $(\boldsymbol{n})$ & Kreirani zapisi (\%) \\
\hline oktober & 17.716 & 10,5 \\
\hline november & 17.041 & 10,1 \\
\hline december & 15.008 & 8,9 \\
\hline september & 14.635 & 8,6 \\
\hline januar & 14.498 & 8,6 \\
\hline marec & 14.102 & 8,3 \\
\hline maj & 13.930 & 8,2 \\
\hline julij & 13.644 & 8,1 \\
\hline junij & 12.797 & 7,6 \\
\hline april & 12.041 & 7,1 \\
\hline avgust & 11.966 & 7,1 \\
\hline februar & 11.848 & 7,0 \\
\hline Skupaj & 169.226 & 100
\end{tabular}

Legenda: $n$-število, \%-odstotek

Prirast bibliografskih zapisov na letni ravni (upoštevani so vsi dnevi v letu) kaže, da je bilo v letu 2018 glede na dan v tednu skupno največ zapisov kreiranih ob torkih. Podrobnosti so predstavljene $v$ tabeli 2 . 
Tabela 2: Prirast bibliografskih zapisov po dnevih v tednu na letni ravni

\begin{tabular}{lllllllll}
\hline Dan & $\begin{array}{l}\text { Dni v } \\
\text { mescu }(\boldsymbol{n})\end{array}$ & $\begin{array}{l}\text { Zapisi } \\
(\boldsymbol{n})\end{array}$ & $\begin{array}{l}\text { Zapisi } \\
(\overline{\boldsymbol{x}})\end{array}$ & $\begin{array}{l}\text { Zapisi } \\
(\boldsymbol{s})\end{array}$ & $\begin{array}{l}\text { Zapisi } \\
(\boldsymbol{\%})\end{array}$ & $\begin{array}{l}\text { Zapisi } \\
(\boldsymbol{m a k s})\end{array}$ & $\begin{array}{l}\text { Zapisi } \\
(\boldsymbol{m i n})\end{array}$ & $\boldsymbol{R}$ \\
\hline ponedeljek & 50 & 32.812 & 656,2 & 166,1 & 19,4 & 921 & 106 & 5 \\
\hline torek & 49 & 34.630 & 706,7 & 107,5 & 20,5 & 975 & 504 & 8 \\
\hline sreda & 48 & 33.588 & 699,8 & 122,3 & 19,8 & 979 & 508 & 7 \\
\hline četrtek & 50 & 33.490 & 669,8 & 136,4 & 19,8 & 1060 & 408 & 6 \\
\hline petek & 51 & 30.496 & 598,0 & 111,0 & 18,0 & 826 & 226 & 4 \\
\hline sobota & 52 & 1.940 & 37,3 & 19,3 & 1,1 & 98 & 7 & 2 \\
\hline nedelja & 52 & 1.973 & 37,9 & 28,3 & 1,2 & 126 & 1 & 3 \\
\hline praznik & 13 & 297 & 22,8 & 14,3 & 0,2 & 49 & 1 & 1 \\
\hline Skupaj & 365 & 169.226 & 463,6 & 314,8 & 100 & 1060 & 1 & $/$ \\
\hline
\end{tabular}

Legenda: $n$-število, $\bar{x}$ - povprečje, $s$ - standardni odklon, \% - delež, maks - maksimum, min minimum, $R$-absolutni rang

Mesečni prirast v letih od 2014 do 2018 je predstavljen na sliki 1. Spremljanje prirasta skozi petletno obdobje kaže na gibanje prirasta bibliografskih zapisov skozi leta. Razvidna je sezonska komponenta, prisotnih pa je tudi nekaj naključnih komponent, ki so vplivale na odstopanja.

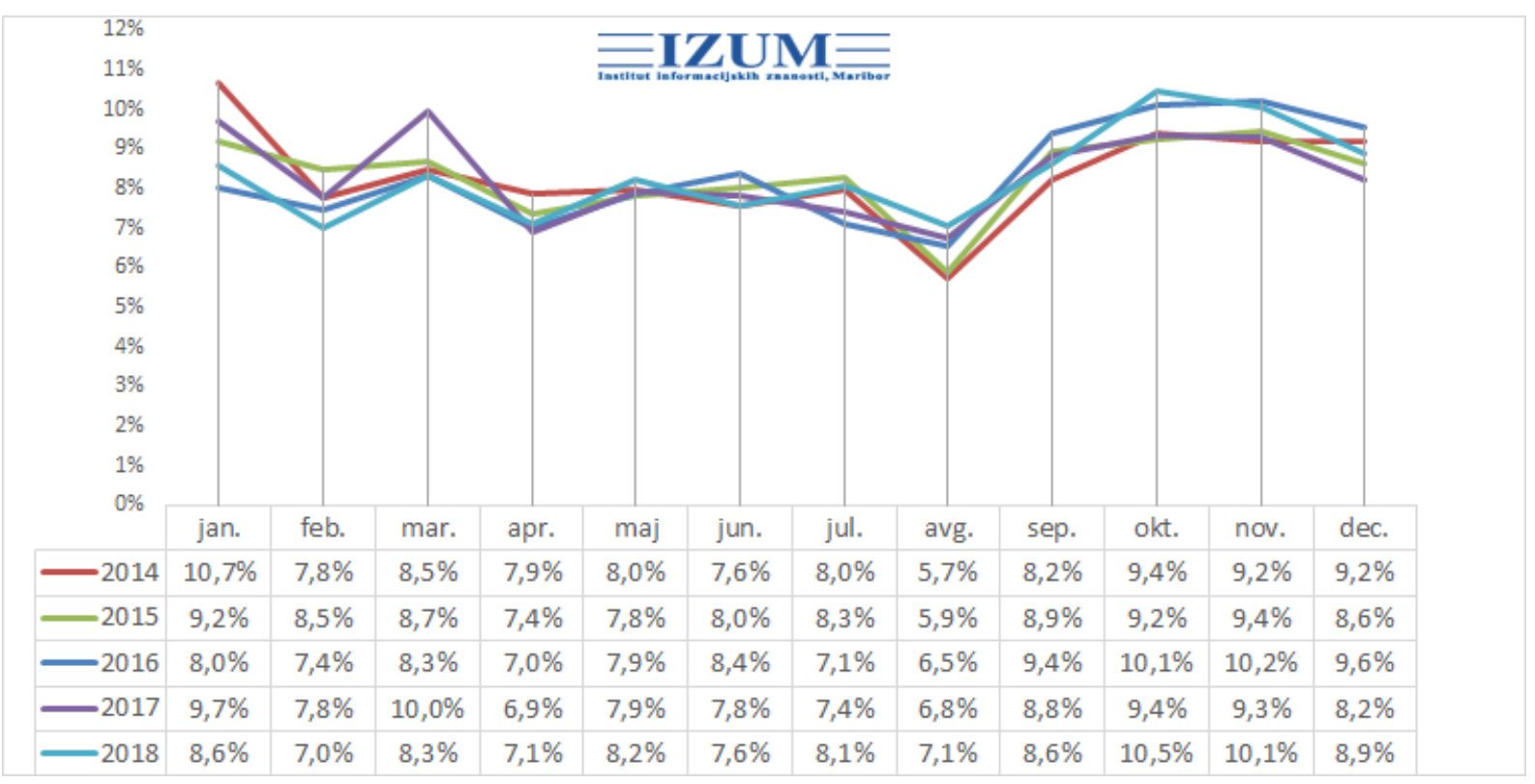

Slika 1: Letni prirast bibliografskih zapisov po mesecih, 2014-2018

\subsection{Mesečni prirast}

V nadaljevanju so predstavljeni podatki o kreiranih bibliografskih zapisih po posameznih mesecih leta 2018.

\subsubsection{Januar}

V 31 dneh januarja je bilo v COBIB.SI dodanih 14.489 bibliografskih zapisov (slika 2), in sicer največ $v$ sredo, 10. 1. 2018. V 21 delovnih dneh je bilo kreiranih 14.100 bibliografskih zapisov. 
Pogled na vse dni v tednu kaže, da je bilo januarja največ zapisov kreiranih v 5 delovnih sredah ( $n=3.384$ ali $24 \%$ ). Povprečni dnevni prirast gradiva $v$ delovnih dneh $(\bar{x})$ je znašal 671,4 zapisa, standardni odklon $(s)$ pa 129,7 . V januarju je bilo na delovni dan kreiranih najmanj 508 in največ 859 zapisov.

COBIB.SI (JAN. 2018)
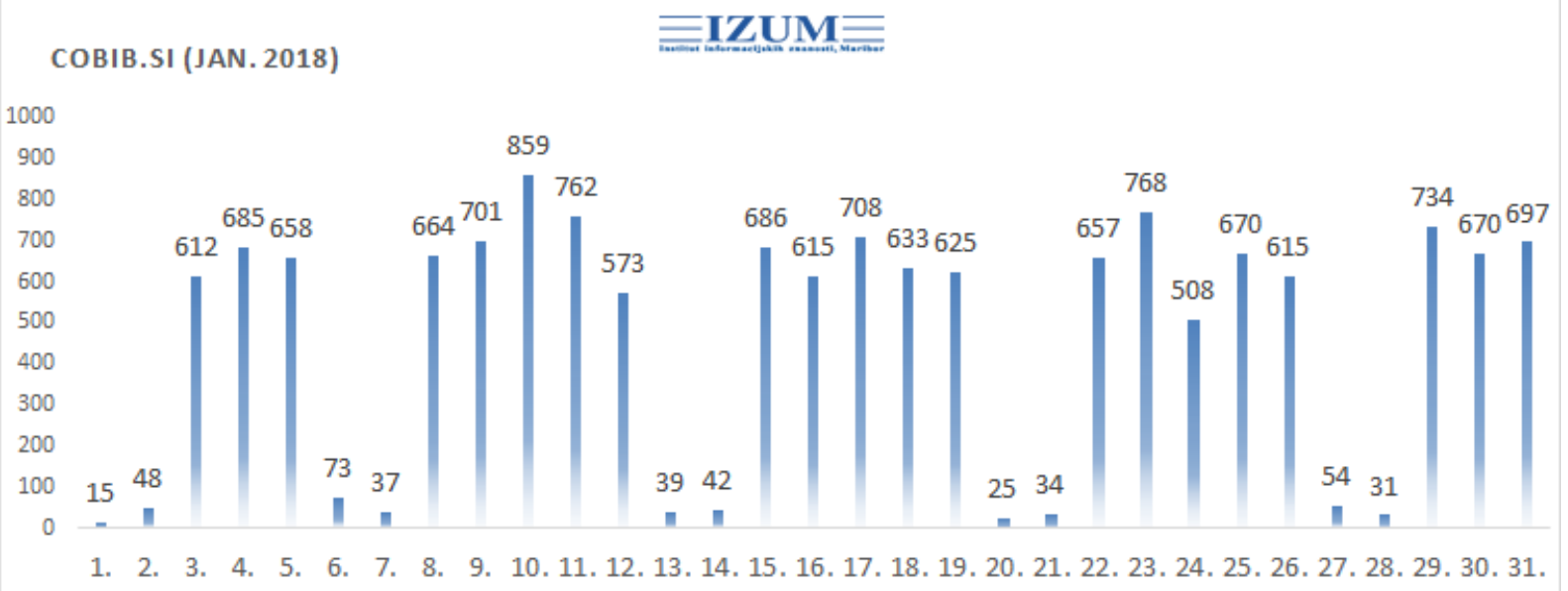

Slika 2: Število bibliografskih zapisov, kreiranih januarja 2018 (podatki na dan 1. 2. 2018)

Povprečni dnevni prirast števila bibliografskih zapisov v 10 dela prostih in prazničnih dneh $(\bar{x})$ je znašal 39,8 zapisa, odklon $(s)$ pa $16,1(n=398)$; na mesečni ravni to predstavlja $2,7 \%$ prirasta. $V$ dela prostih dneh je bilo kreiranih najmanj 15 in največ 73 zapisov na dan. Zapisi, kreirani januarja, predstavljajo 8,6\% celoletnega prirasta, tako januar po številu kreiranih zapisov na letni ravni po rangu prirasta po mesecih zaseda 5. mesto. Podrobnosti prirasta $v$ januarju so predstavljene $v$ tabeli 3 (podatki so razvrščeni glede na rang).

Tabela 3: Bibliografski zapisi, kreirani januarja 2018

\begin{tabular}{lllllllll}
\hline Dan & $\begin{array}{l}\text { Dni v } \\
\text { mescu }(\boldsymbol{n})\end{array}$ & $\begin{array}{l}\text { Zapisi } \\
(\boldsymbol{n})\end{array}$ & $\begin{array}{l}\text { Zapisi } \\
(\overline{\boldsymbol{x}})\end{array}$ & $\begin{array}{l}\text { Zapisi } \\
(\boldsymbol{s})\end{array}$ & $\begin{array}{l}\text { Zapisi } \\
(\boldsymbol{\%})\end{array}$ & $\begin{array}{l}\text { Zapisi } \\
(\boldsymbol{m a k s})\end{array}$ & $\begin{array}{l}\text { Zapisi } \\
(\boldsymbol{m i n})\end{array}$ & $\boldsymbol{R}$ \\
\hline sreda & 5 & 3.384 & 676,8 & 129,7 & 23,3 & 859 & 508 & 8 \\
\hline torek & 4 & 2.754 & 688,5 & 63,8 & 19,0 & 768 & 615 & 7 \\
\hline četrtek & 4 & 2.750 & 687,5 & 54,3 & 19,0 & 762 & 633 & 6 \\
\hline ponedeljek & 4 & 2.741 & 685,3 & 34,8 & 18,9 & 734 & 657 & 5 \\
\hline petek & 4 & 2.471 & 617,8 & 35,0 & 17,0 & 658 & 573 & 4 \\
\hline sobota & 4 & 191 & 47,8 & 20,6 & 1,3 & 73 & 25 & 3 \\
\hline nedelja & 4 & 144 & 36,0 & 4,7 & 1,0 & 42 & 31 & 2 \\
\hline praznik & 2 & 63 & 31,5 & 23,3 & 0,4 & 48 & 15 & 1 \\
\hline Skupaj & 31 & 14.498 & 467,7 & 306,3 & 100 & 859 & 15 & $/$ \\
\hline
\end{tabular}

Legenda: $n$ - število, $\bar{x}$ - povprečje, $s$ - standardni odklon, \% - delež, maks - maksimum, min minimum, $R$-absolutni rang

\subsubsection{Februar}

V februarju 2018 je bilo kreiranih 11.848 zapisov (slika 3), od tega $\vee 19$ delovnih dneh povprečno $(\bar{x}) 607$ zapisov na dan, odklon $(s)$ pa je znašal 55,7. 


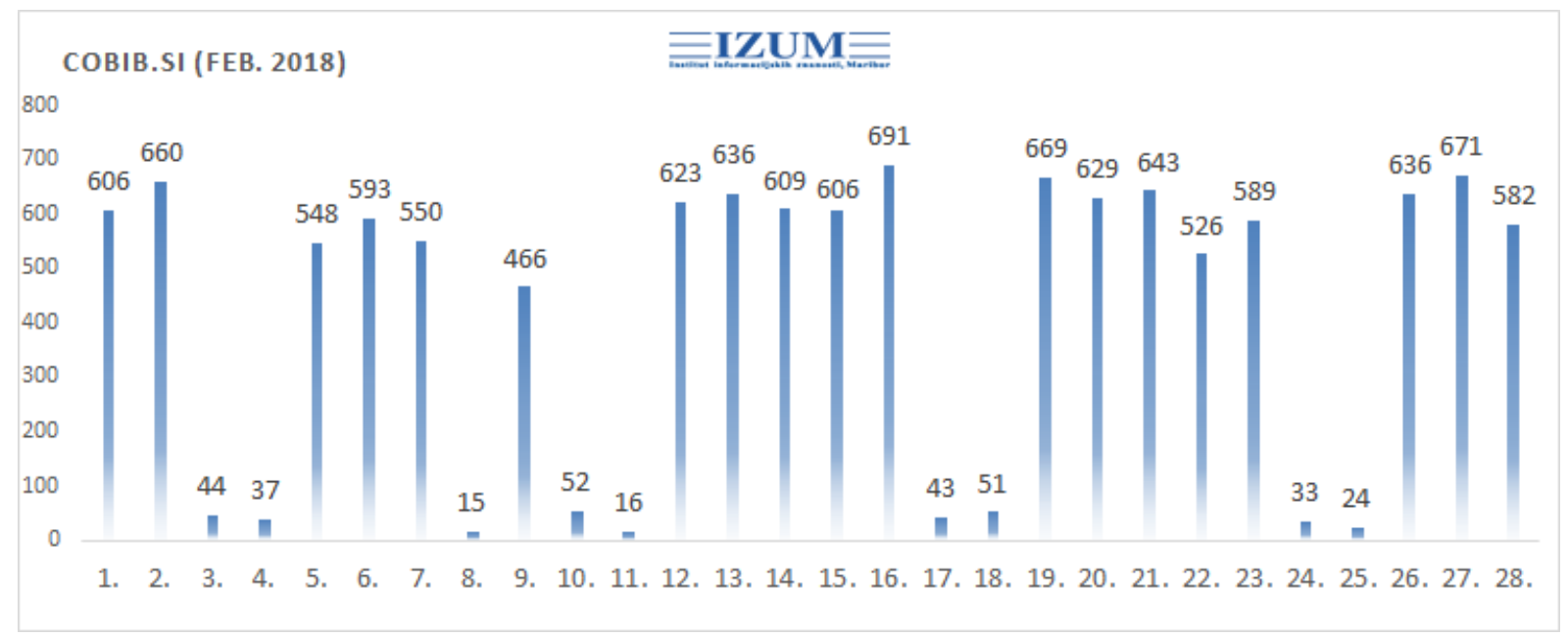

Slika 3: Število bibliografskih zapisov, kreiranih februarja 2018 (podatki na dan 1. 3. 2018)

Zapisi, kreirani $v$ februarju, predstavljajo $7 \%$ letnega prirasta, tako je februar po številu kreiranih zapisov na zadnjem (12.) mestu. Največ zapisov na posamezen dan je bilo kreiranih v petek, 16. 2. 2018, in to 691, sicer pa je bil v februarju najbolj produktiven dan v delovnem tednu torek. Štirje delovni torki $v$ mesecu so prinesli $21,3 \%$ mesečnega prirasta. Celoten mesečni prirast je predstavljen $v$ tabeli 4 (podatki so razvrščeni glede na rang).

Tabela 4: Bibliografski zapisi, kreirani februarja 2018

\begin{tabular}{lllllllll}
\hline Dan & $\begin{array}{l}\text { Dni v } \\
\text { mescu }(\boldsymbol{n})\end{array}$ & $\begin{array}{l}\text { Zapisi } \\
(\boldsymbol{n})\end{array}$ & $\begin{array}{l}\text { Zapisi } \\
(\overline{\boldsymbol{x}})\end{array}$ & $\begin{array}{l}\text { Zapisi } \\
(\boldsymbol{s})\end{array}$ & $\begin{array}{l}\text { Zapisi } \\
(\mathbf{\% )}\end{array}$ & $\begin{array}{l}\text { Zapisi } \\
(\mathbf{m a k s})\end{array}$ & $\begin{array}{l}\text { Zapisi } \\
(\boldsymbol{m i n})\end{array}$ & $\boldsymbol{R}$ \\
\hline torek & 4 & 2.529 & 632,3 & 32,0 & 21,3 & 671 & 593 & 8 \\
\hline ponedeljek & 4 & 2.476 & 619,0 & 51,1 & 20,9 & 669 & 548 & 7 \\
\hline petek & 4 & 2.406 & 601,5 & 99,9 & 20,3 & 691 & 466 & 6 \\
\hline sreda & 4 & 2.384 & 596,0 & 39,5 & 20,1 & 643 & 550 & 5 \\
\hline četrtek & 3 & 1.738 & 579,3 & 46,2 & 14,7 & 606 & 526 & 4 \\
\hline sobota & 4 & 172 & 43,0 & 7,8 & 1,5 & 52 & 33 & 3 \\
\hline nedelja & 4 & 128 & 32,0 & 15,3 & 1,1 & 51 & 16 & 2 \\
\hline praznik & 1 & 15 & 15,0 & $/$ & 0,1 & 15 & 15 & 1 \\
\hline Skupaj & 28 & 11.848 & 423,1 & 275,9 & 100 & 691 & 15 & $/$ \\
\hline
\end{tabular}

Legenda: $n$ - število, $\bar{x}$ - povprečje, $s$ - standardni odklon, \% - delež, maks - maksimum, min minimum, $R$-absolutni rang

\subsubsection{Marec}

$\mathrm{V}$ marcu so katalogizatorji $\vee$ COBIB.SI prispevali 14.102 bibliografska zapisa, od tega $\mathrm{v} 22$ delovnih dneh $13.785(\bar{x}=626,6 ; s=61,9 ;$ maks $=775 ; \min =507)$, v 9 dela prostih dneh pa še dodatnih $317(\underline{\bar{x}}=35,2, s=24,1 ;$ maks $=79 ; \min =7)$ (slika 4). Zapisi, kreirani v marcu, predstavljajo 8,3 \% letnega prirasta in so na 6 . mestu glede na letni prirast po mesecih. 


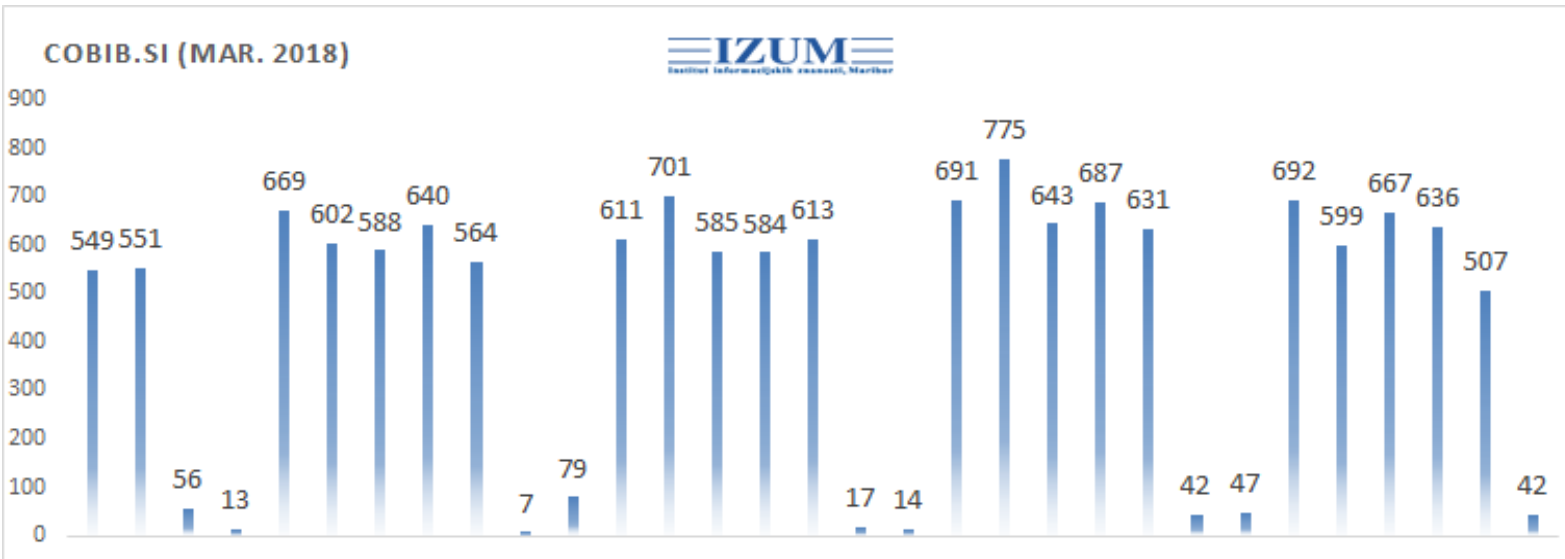

1. 2. 3. 4. 5. 6. 7. 8. 9. 10.11. 12. 13. 14. 15. 16. 17. 18. 19. 20. 21. 22. 23. 24. 25. 26. 27. 28. 29. 30. 31.

Slika 4: Število bibliografskih zapisov, kreiranih marca 2018 (podatki na dan 3. 4. 2018)

Enako kot leto prej je bilo marca največ zapisov kreiranih ob četrtkih $(n=5)$, in sicer 3.096 (22 \%), sledijo petki z 2.866 (20,3\%), torki z 2.677 (19\%), ponedeljki z 2.663 (18,9\%) in srede z 2.483 (17,6 \%) kreiranimi zapisi. Podrobnosti mesečnega prirasta so predstavljene v tabeli 5 (podatki so razvrščeni glede na rang). Največ zapisov, kreiranih na posamezni dan meseca, je bilo v torek, 20. 3. $2018(n=775)$.

Tabela 5: Bibliografski zapisi, kreirani marca 2018

\begin{tabular}{lllllllll}
\hline Dan & $\begin{array}{l}\text { Dni v } \\
\text { mescu }(\boldsymbol{n})\end{array}$ & $\begin{array}{l}\text { Zapisi } \\
(\boldsymbol{n})\end{array}$ & $\begin{array}{l}\text { Zapisi } \\
(\overline{\boldsymbol{x}})\end{array}$ & $\begin{array}{l}\text { Zapisi } \\
(\boldsymbol{s})\end{array}$ & $\begin{array}{l}\text { Zapisi } \\
(\%)\end{array}$ & $\begin{array}{l}\text { Zapisi } \\
(\boldsymbol{m a k s})\end{array}$ & $\begin{array}{l}\text { Zapisi } \\
(\boldsymbol{m i n})\end{array}$ & $\boldsymbol{R}$ \\
\hline četrtek & 5 & 3.096 & 619,2 & 53,6 & 22,0 & 687 & 549 & 7 \\
\hline petek & 5 & 2.866 & 573,2 & 49,7 & 20,3 & 631 & 507 & 6 \\
\hline torek & 4 & 2.677 & 669,3 & 84,9 & 19,0 & 775 & 599 & 5 \\
\hline ponedeljek & 4 & 2.663 & 665,8 & 38,0 & 18,9 & 692 & 611 & 4 \\
\hline sreda & 4 & 2.483 & 620,8 & 40,8 & 17,6 & 667 & 585 & 3 \\
\hline sobota & 5 & 164 & 32,8 & 20,1 & 1,2 & 56 & 7 & 2 \\
\hline nedelja & 4 & 153 & 38,3 & 31,4 & 1,1 & 79 & 13 & 1 \\
\hline Skupaj & 31 & 14.102 & 454,9 & 278,0 & 100 & 775 & 7 & $/$ \\
\hline
\end{tabular}

Legenda: $n$ - število, $\bar{x}$ - povprečje, $s$ - standardni odklon, \% - delež, maks - maksimum, min minimum, $R$-absolutni rang

\subsubsection{April}

Aprila se je baza COBIB.SI povečala za 12.041 bibliografskih zapisov (slika 5). Največ bibliografskih zapisov, in sicer 751, je bilo kreiranih v torek, 17. 4. 2018. 


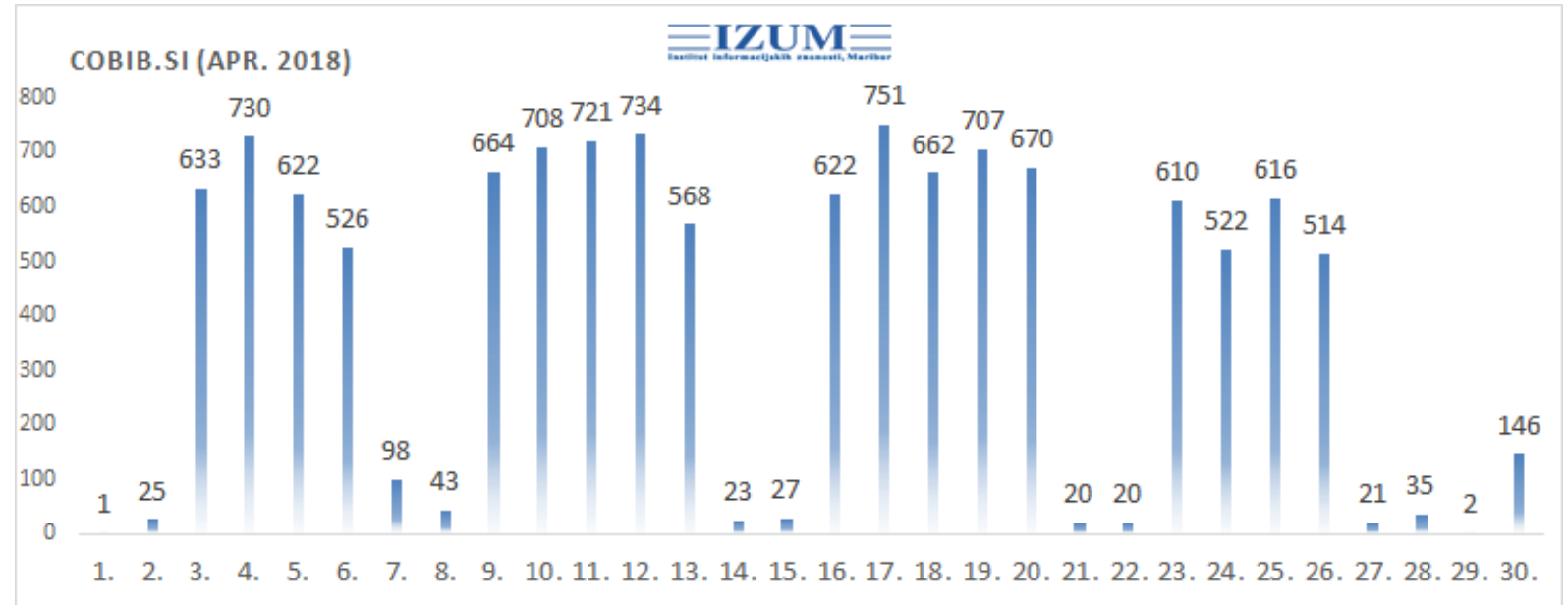

Slika 5: Število bibliografskih zapisov, kreiranih aprila 2018 (podatki na dan 3. 5. 2018)

Največji skupni prirast bibliografskih zapisov $v$ delovnih dneh $v$ aprilu beležimo ob sredah. $\mathrm{V}$ 19 delovnih dnevih je povprečni dnevni prirast števila bibliografskih zapisov $(\bar{x})$ znašal 617,2 zapisa, odklon (s) je bil 135,6. Podrobnosti prirasta so predstavljene $v$ tabeli 6 (podatki so razvrščeni glede na rang).

Tabela 6: Bibliografski zapisi, kreirani aprila 2018

\begin{tabular}{lllllllll}
\hline Dan & $\begin{array}{l}\text { Dni v } \\
\text { mescu }(\boldsymbol{n})\end{array}$ & $\begin{array}{l}\text { Zapisi } \\
(\boldsymbol{n})\end{array}$ & $\begin{array}{l}\text { Zapisi } \\
(\overline{\boldsymbol{x}})\end{array}$ & $\begin{array}{l}\text { Zapisi } \\
(\boldsymbol{s})\end{array}$ & $\begin{array}{l}\text { Zapisi } \\
(\mathbf{\%})\end{array}$ & $\begin{array}{l}\text { Zapisi } \\
(\boldsymbol{m a k s})\end{array}$ & $\begin{array}{l}\text { Zapisi } \\
(\boldsymbol{m i n})\end{array}$ & $\boldsymbol{R}$ \\
\hline sreda & 4 & 2.729 & 682,3 & 53,5 & 22,7 & 730 & 616 & 8 \\
\hline torek & 4 & 2.614 & 653,5 & 100,3 & 21,7 & 751 & 522 & 7 \\
\hline četrtek & 4 & 2.577 & 644,3 & 99,1 & 21,4 & 734 & 514 & 6 \\
\hline ponedeljek & 4 & 2.042 & 510,5 & 244,1 & 17,0 & 664 & 146 & 5 \\
\hline petek & 3 & 1.764 & 588,0 & 74,1 & 14,6 & 670 & 526 & 4 \\
\hline sobota & 4 & 176 & 44,0 & 36,6 & 1,5 & 98 & 20 & 3 \\
\hline nedelja & 5 & 93 & 18,6 & 17,7 & 0,8 & 43 & 1 & 2 \\
\hline praznik & 2 & 46 & 23,0 & 2,8 & 0,4 & 25 & 21 & 1 \\
\hline Skupaj & 30 & 12.041 & 401,4 & 308,0 & 100 & 751 & 1 & $/$ \\
\hline
\end{tabular}

Legenda: $n$ - število, $\bar{x}$ - povprečje, $s$ - standardni odklon, \% - delež, maks - maksimum, min minimum, $R$-absolutni rang

April je imel 11 dela prostih dni, za katere beležimo 315 kreiranih zapisov $(\bar{x}=28,6, s=26,1)$. Na letni ravni predstavljajo bibliografski zapisi, kreirani aprila, 7,1 \%, tako da je april na 10. mestu po številu kreiranih zapisov.

\subsubsection{Maj}

Zapisi, kreirani maja 2018, predstavljajo 8,2 \% letnega prirasta bibliografskih zapisov ( $n=$ 13.930). Maj je na 7. mestu glede skupnega števila kreiranih zapisov po mesecih. Na sliki 6 je razvidno, da je bil torek, 22. 5. 2018, s 777 zapisi dan, ko je bil dnevni prirast bibliografskih zapisov najvišji, sledita sreda, 23. 5. 2018, s 774 zapisi in četrtek, 17. 5. 2018, s 729 zapisi. 


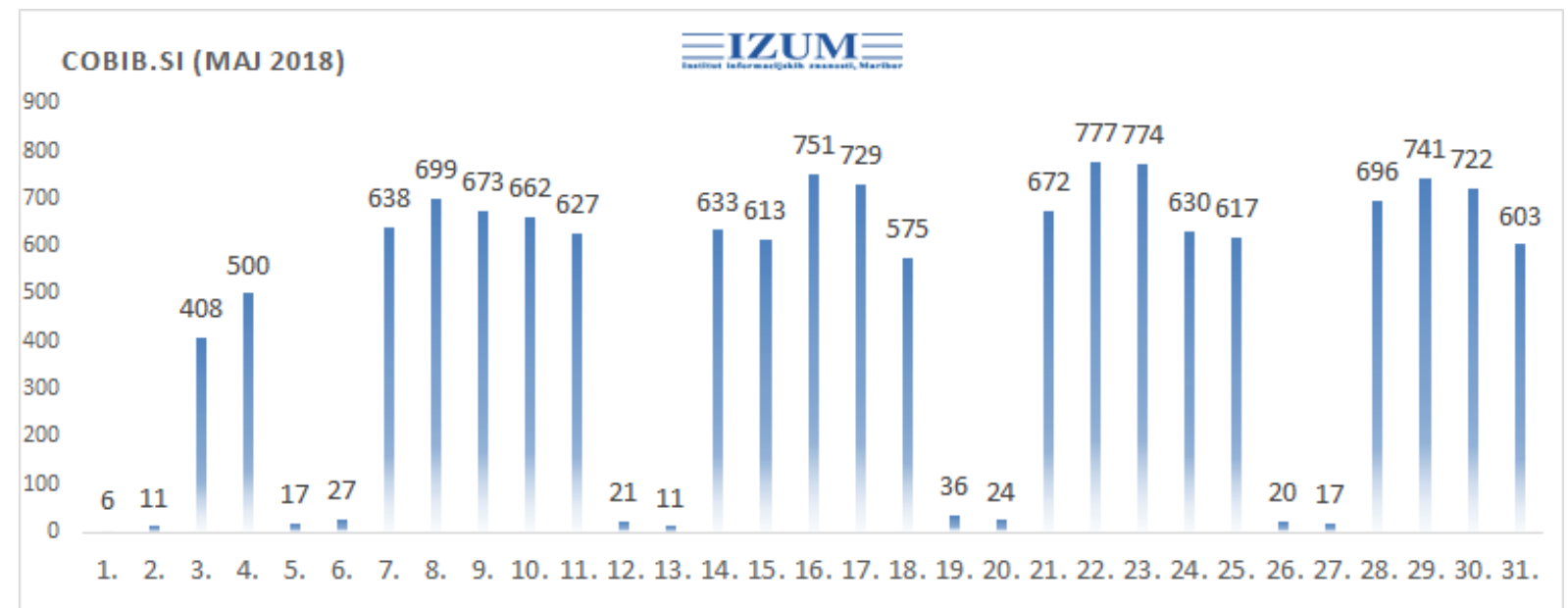

Slika 6: Število bibliografskih zapisov, kreiranih maja 2018 (podatki na dan 4. 6. 2018)

Skupno število zapisov, kreiranih $v 20$ delovnih dneh $v$ maju, je 13.137. $\vee$ maju je bilo pet četrtkov in ti so na prvem mestu po kreiranih zapisih glede na dan $v$ tednu $(21,8 \%)$, sledijo štiri srede $(21 \%)$ in štirje torki $(20,3 \%)$. V 10 dela prostih dneh so katalogizatorji v COBIB.SI dopolnili 190 bibliografskih zapisov $(\bar{x}=19, s=8,7)$. Podrobnosti vseh dni $v$ mesecu so predstavljene $v$ tabeli 7 , dnevi so razvrščeni glede na rang.

Tabela 7: Bibliografski zapisi, kreirani maja 2018

\begin{tabular}{lllllllll}
\hline Dan & $\begin{array}{l}\text { Dni v } \\
\text { mescu }(\boldsymbol{n})\end{array}$ & $\begin{array}{l}\text { Zapisi } \\
(\boldsymbol{n})\end{array}$ & $\begin{array}{l}\text { Zapisi } \\
(\overline{\boldsymbol{x}})\end{array}$ & $\begin{array}{l}\text { Zapisi } \\
(\boldsymbol{s})\end{array}$ & $\begin{array}{l}\text { Zapisi } \\
(\%)\end{array}$ & $\begin{array}{l}\text { Zapisi } \\
(\boldsymbol{m a k s})\end{array}$ & $\begin{array}{l}\text { Zapisi } \\
(\boldsymbol{m i n})\end{array}$ & $\boldsymbol{R}$ \\
\hline četrtek & 5 & 3.032 & 606,4 & 120,5 & 21,8 & 729 & 408 & 8 \\
\hline sreda & 4 & 2.920 & 730,0 & 43,6 & 21,0 & 774 & 673 & 7 \\
\hline torek & 4 & 2.830 & 707,5 & 70,6 & 20,3 & 777 & 613 & 6 \\
\hline ponedeljek & 4 & 2.639 & 659,8 & 29,7 & 18,9 & 696 & 633 & 5 \\
\hline petek & 4 & 2.319 & 579,8 & 57,7 & 16,6 & 627 & 500 & 4 \\
\hline sobota & 4 & 94 & 23,5 & 8,5 & 0,7 & 36 & 17 & 3 \\
\hline nedelja & 4 & 79 & 19,8 & 7,2 & 0,6 & 27 & 11 & 2 \\
\hline praznik & 2 & 17 & 8,5 & 3,5 & 0,1 & 11 & 6 & 1 \\
\hline Skupaj & 31 & 13.930 & 449,4 & 310,6 & 100 & 777 & 6 & $/$ \\
\hline
\end{tabular}

Legenda: $n$ - število, $\bar{x}$ - povprečje, $s$ - standardni odklon, \% - delež, maks - maksimum, min minimum, $R$-absolutni rang

\subsubsection{Junij}

V 30 dneh junija je bilo kreiranih 12.797 bibliografskih zapisov. Mesečni prirast v juniju predstavlja 7,6 \%, tako da je junij na 9. mestu po številu prirasta bibliografskih zapisov na letni ravni. Glede na dneve v tednu je bilo junija (kumulativno po dnevih) največ zapisov $(n=2.674$ ) kreiranih $v 5$ petkih. Glede na posamezen dan $v$ mesecu je bilo največ zapisov kreiranih $v$ ponedeljek, 18. 6. 2018, in sicer 821 (slika 7). 


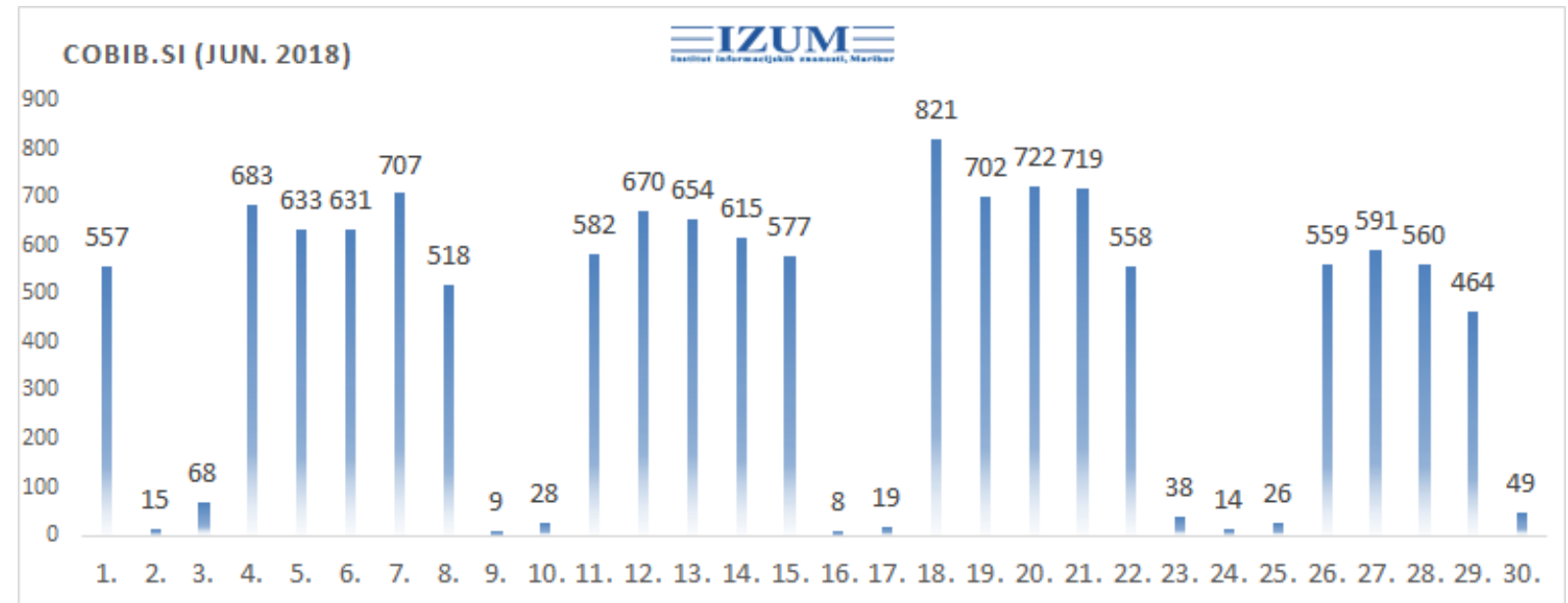

Slika 7: Število bibliografskih zapisov, kreiranih junija 2018 (podatki na dan 2. 7. 2018)

$\checkmark 20$ delovnih dneh je bilo kreiranih 12.523 bibliografskih zapisov, na delovni dan je povprečni prirast $(\bar{x})$ znašal 626,2 , odklon (s) pa 84,6 zapisa. Zapisi, kreirani v 10 dela prostih dneh (petih sobotah, štirih nedeljah in enem prazničnem dnevu), predstavljajo 2,1-odstotni delež prirasta v juniju ( $n=274, \bar{x}=27,4, s=19,3$ ). Kumulativni podatki za vse dni v juniju so predstavljeni $v$ tabeli 8 (podatki so razvrščeni po dneh tedna).

Tabela 8: Bibliografski zapisi, kreirani junija 2018

\begin{tabular}{lllllllll}
\hline Dan & $\begin{array}{l}\text { Dni v } \\
\text { mescu }(\boldsymbol{n})\end{array}$ & $\begin{array}{l}\text { Zapisi } \\
(\boldsymbol{n})\end{array}$ & $\begin{array}{l}\text { Zapisi } \\
(\overline{\boldsymbol{x}})\end{array}$ & $\begin{array}{l}\text { Zapisi } \\
(\boldsymbol{s})\end{array}$ & $\begin{array}{l}\text { Zapisi } \\
(\mathbf{\%})\end{array}$ & $\begin{array}{l}\text { Zapisi } \\
(\mathbf{m a k s})\end{array}$ & $\begin{array}{l}\text { Zapisi } \\
(\boldsymbol{m i n})\end{array}$ & $\boldsymbol{R}$ \\
\hline ponedeljek & 3 & 2.086 & 695,3 & 120,0 & 16,3 & 821 & 582 & 4 \\
\hline torek & 4 & 2.564 & 641,0 & 61,5 & 20,0 & 702 & 559 & 5 \\
\hline sreda & 4 & 2.598 & 649,5 & 54,9 & 20,3 & 722 & 591 & 6 \\
\hline četrtek & 4 & 2.601 & 650,3 & 76,0 & 20,3 & 719 & 560 & 7 \\
\hline petek & 5 & 2.674 & 534,8 & 45,0 & 20,9 & 577 & 464 & 8 \\
\hline sobota & 5 & 119 & 23,8 & 18,6 & 0,9 & 49 & 8 & 2 \\
\hline nedelja & 4 & 129 & 32,3 & 24,5 & 1,0 & 68 & 14 & 3 \\
\hline praznik & 1 & 26 & 26,0 & $/$ & 0,2 & 26 & 26 & 1 \\
\hline Skupaj & 30 & 12.797 & 426,6 & 295,3 & 100 & 821 & 8 & $/$
\end{tabular}

Legenda: $n$ - število, $\bar{x}$ - povprečje, $s$ - standardni odklon, \% - delež, maks - maksimum, min minimum, $R$-absolutni rang

\subsubsection{Julij}

Prirast bibliografskih zapisov v COBIB.SI obsega 13.644 zapisov (slika 8). Največ zapisov v tem mesecu je bilo kreiranih v sredo, 11. 7. 2018, in sicer 724. 
COBIB.SI (JUL. 2018)

\section{$\equiv \mathbf{I Z U M} \equiv$}

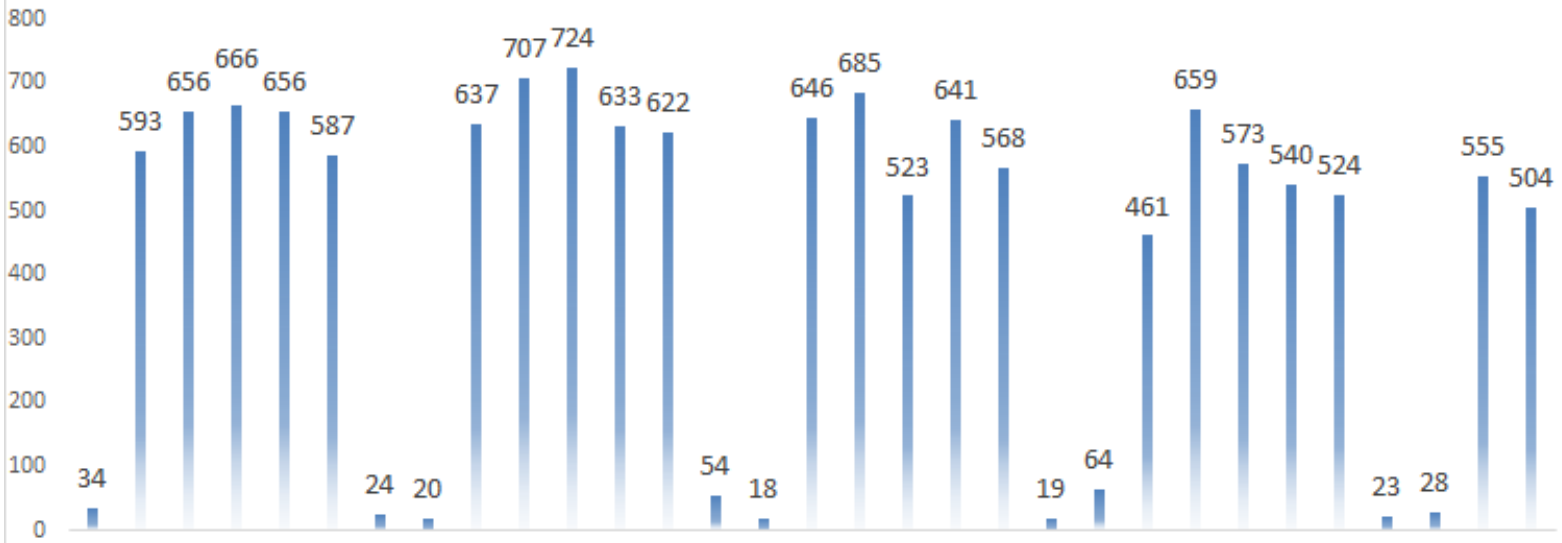

1. 2. 3. 4. 5. 6. 7. 8. 9. 10.11. 12. 13.14. 15. 16. 17. 18. 19. 20. 21. 22. 23. 24. 25. 26. 27. 28. 29. 30. 31.

Slika 8: Število bibliografskih zapisov, kreiranih julija 2018 (podatki na dan 1. 8. 2018)

Na mesečni ravni (zajeti so vsi dnevi) so katalogizatorji kreirali največ zapisov ob torkih, in sicer $23,5 \%(n=3.211, \bar{x}=642,2, s=80)$. Torkom sledijo ponedeljki (tabela 9, podatki so razvrščeni glede na rang).

Tabela 9: Bibliografski zapisi, kreirani julija 2018

\begin{tabular}{lllllllll}
\hline Dan & $\begin{array}{l}\text { Dni v } \\
\text { mescu }(\boldsymbol{n})\end{array}$ & $\begin{array}{l}\text { Zapisi } \\
(\boldsymbol{n})\end{array}$ & $\begin{array}{l}\text { Zapisi } \\
(\overline{\boldsymbol{x}}) \mathbf{)}\end{array}$ & $\begin{array}{l}\text { Zapisi } \\
(\boldsymbol{s})\end{array}$ & $\begin{array}{l}\text { Zapisi } \\
(\%)\end{array}$ & $\begin{array}{l}\text { Zapisi } \\
(\boldsymbol{m a k s})\end{array}$ & $\begin{array}{l}\text { Zapisi } \\
(\boldsymbol{m i n})\end{array}$ & $\boldsymbol{R}$ \\
\hline torek & 5 & 3.211 & 642,2 & 80,0 & 23,5 & 707 & 504 & 7 \\
\hline ponedeljek & 5 & 2.892 & 578,4 & 75,1 & 21,2 & 646 & 461 & 6 \\
\hline sreda & 4 & 2.486 & 621,5 & 90,4 & 18,2 & 724 & 523 & 5 \\
\hline četrtek & 4 & 2.470 & 617,5 & 52,5 & 18,1 & 656 & 540 & 4 \\
\hline petek & 4 & 2.301 & 575,3 & 40,8 & 16,9 & 622 & 524 & 3 \\
\hline nedelja & 5 & 164 & 32,8 & 18,6 & 1,2 & 64 & 18 & 2 \\
\hline sobota & 4 & 120 & 30,0 & 16,1 & 0,9 & 54 & 19 & 1 \\
\hline Skupaj & 31 & 13.644 & 440,1 & 272,1 & 100 & 724 & 18 & $/$ \\
\hline
\end{tabular}

Legenda: $n$ - število, $\bar{x}$ - povprečje, s - standardni odklon, \% - delež, maks - maksimum, min minimum, $R$-absolutni rang

Bibliografski zapisi, kreirani v tem mesecu, predstavljajo 8,1 \% letnega prirasta, tako je julij, kljub temu da je poletni mesec, ko je čas letnih dopustov, na 8. mestu glede na letni prirast. Povprečni dnevni prirast števila bibliografskih zapisov $(\bar{x}) \vee 22$ delovnih dneh je bil 607,3, odklon $(s)$ pa 69,5 ( $n=13.360)$ zapisa. $\vee 9$ dela prostih dneh je bilo kreiranih 284 zapisov $(2,1 \%)$, povprečni dnevni prirast $(\bar{x}) \vee$ dela prostih dneh je znašal 31,6 , standardni odklon $(s)$ pa 16,5 .

\subsubsection{Avgust}

Avgust je po prirastu bibliografskih zapisov na predzadnjem mestu s 7,1 \% kreiranih zapisov ( $n$ $=11.966)$. $\vee 22$ delovnih dneh je bil povprečni dnevni prirast $(\bar{x}) 531,1$ zapisa, odklon $(s)$ je bil 
78,4; skupno število kreiranih zapisov je znašalo 11.685. V 9 dela prostih dneh je bilo kreiranih 281 bibliografskih zapisov, povprečni dnevni prirast gradiva $(\bar{x})$ je znašal 31,2 , odklon $(s)$ pa 36,7 zapisa. $V$ prikaz podatkov $v$ tabeli 10 so vključeni vsi dnevi meseca, podatki so razvrščeni po dnevih $v$ tednu.

Tabela 10: Bibliografski zapisi, kreirani v mesecu avgustu 2018

\begin{tabular}{|c|c|c|c|c|c|c|c|c|}
\hline Dan & $\begin{array}{l}\text { Dni v } \\
\text { mescu (n) }\end{array}$ & $\begin{array}{l}\text { Zapisi } \\
(n)\end{array}$ & $\begin{array}{l}\text { Zapisi } \\
(\bar{x})\end{array}$ & $\begin{array}{l}\text { Zapisi } \\
\text { (s) }\end{array}$ & $\begin{array}{l}\text { Zapisi } \\
(\%)\end{array}$ & $\begin{array}{l}\text { Zapisi } \\
\text { (maks) }\end{array}$ & $\begin{array}{l}\text { Zapisi } \\
\text { (min) }\end{array}$ & $R$ \\
\hline ponedeljek & 4 & 2.184 & 546,0 & 52,4 & 18,3 & 614 & 490 & 4 \\
\hline torek & 4 & 2.480 & 620,0 & 94,2 & 20,7 & 741 & 538 & 8 \\
\hline sreda & 4 & 2.203 & 550,8 & 67,2 & 18,4 & 651 & 508 & 5 \\
\hline četrtek & 5 & 2.460 & 492,0 & 35,5 & 20,6 & 527 & 448 & 7 \\
\hline petek & 5 & 2.358 & 471,6 & 63,9 & 19,7 & 541 & 374 & 6 \\
\hline sobota & 4 & 84 & 21,0 & 8,0 & 0,7 & 30 & 12 & 2 \\
\hline nedelja & 4 & 167 & 41,8 & 56,9 & 1,4 & 126 & 1 & 3 \\
\hline praznik & 1 & 30 & 30,0 & / & 0,3 & 30 & 30 & 1 \\
\hline Skupaj & 31 & 11.966 & 386 & 240,6 & 100 & 741 & 1 & / \\
\hline
\end{tabular}

Legenda: $n$ - število, $\bar{x}$ - povprečje, $s$ - standardni odklon, \% - delež, maks - maksimum, min minimum, $R$-absolutni rang

Drugič v letu 2018 se je zgodilo, da je bil na dan kreiran le en bibliografski zapis. Gre za dela prosto nedeljo, 12. 8. Največ zapisov je bilo kreiranih $v$ torek, 7. 8. 2018, in sicer 741 , sledita sreda, 8. 8. 2018, s 651 in torek, 21. 8. 2018, s 648 zapisi (slika 9).

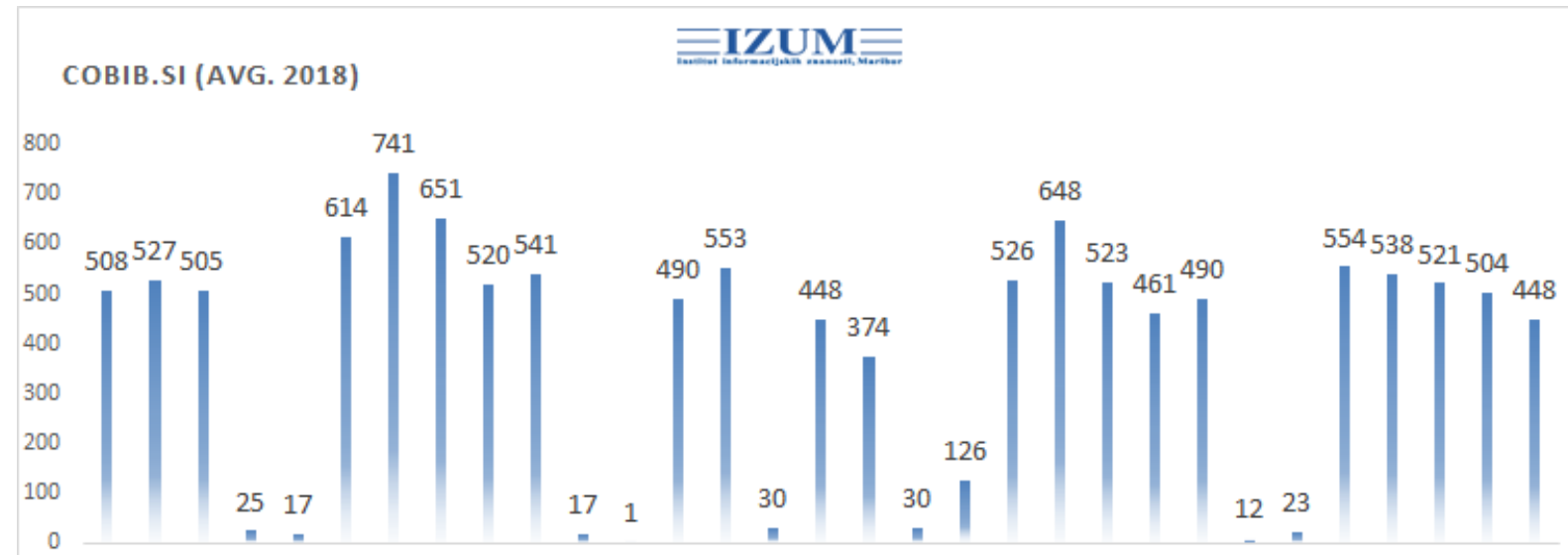

1. 2. 3. 4. 5. 6. 7. 8. 9. 10.11.12.13.14.15.16.17. 18. 19. 20. 21. 22. 23. 24. 25. 26. 27. 28. 29. 30. 31.

Slika 9: Število bibliografskih zapisov, kreiranih avgusta 2018 (podatki na dan 3. 9. 2018)

Čeprav je bilo v avgustu 5 četrtkov in 5 petkov, ta dva dneva v tednu nista zaslužna za (naj)večje število kreiranih zapisov. Najbolj produktivni delovni dnevi glede na dan v tednu so bili torki; v 4 torkih je bilo kreiranih $20,7 \%(n=2.480, \bar{x}=620, s=94,2)$ zapisov, sledijo četrtki z $20,6 \%$ in petki z $19,7 \%$ mesečnega prirasta.

\subsubsection{September}

September je na 4. mestu po številu kreiranih zapisov na letni ravni $(8,6 \%, n=14.635)$. Linearni trend mesečnega prirasta kaže na porast proti koncu meseca, skupno število kreiranih 
zapisov je v drugi polovici meseca za $4,8 \%$ višje v primerjavi s prvo polovico meseca. Največ zapisov $v$ tem mesecu $(n=839)$ je bilo kreiranih $v$ sredo, 26. 9. 2018, sledita četrtek, 27. 9. 2018, z 837 in ponedeljek, 24. 9. 2018, z 834 kreiranimi bibliografskimi zapisi (slika 10).

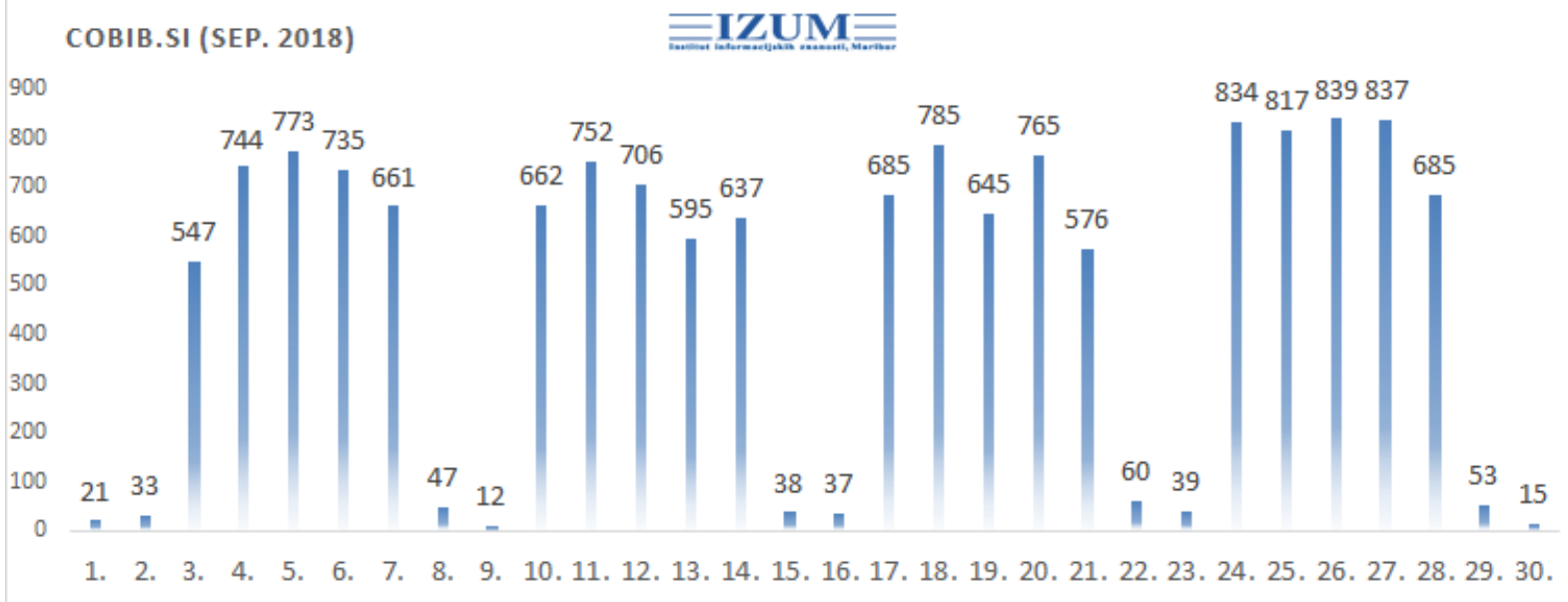

Slika 10: Število bibliografskih zapisov, kreiranih septembra 2018 (podatki na dan 1. 10. 2018)

Podrobni podatki o mesečnem prirastu za vse dni v septembru so predstavljeni v tabeli 11.

Tabela 11: Bibliografski zapisi, kreirani v mesecu septembru 2018

\begin{tabular}{lllllllll}
\hline Dan & $\begin{array}{l}\text { Dni v } \\
\text { mescu }(\boldsymbol{n})\end{array}$ & $\begin{array}{l}\text { Zapisi } \\
(\boldsymbol{n})\end{array}$ & $\begin{array}{l}\text { Zapisi } \\
(\overline{\boldsymbol{x}})\end{array}$ & $\begin{array}{l}\text { Zapisi } \\
(\boldsymbol{s})\end{array}$ & $\begin{array}{l}\text { Zapisi } \\
(\%)\end{array}$ & $\begin{array}{l}\text { Zapisi } \\
(\boldsymbol{m a k s})\end{array}$ & $\begin{array}{l}\text { Zapisi } \\
(\boldsymbol{m i n})\end{array}$ & $\boldsymbol{R}$ \\
\hline ponedeljek & 4 & 2.728 & 682,0 & 118,0 & 18,6 & 834 & 547 & 4 \\
\hline torek & 4 & 3.098 & 774,5 & 33,4 & 21,2 & 817 & 744 & 7 \\
\hline sreda & 4 & 2.963 & 740,8 & 83,8 & 20,2 & 839 & 645 & 6 \\
\hline četrtek & 4 & 2.932 & 733,0 & 101,5 & 20,0 & 837 & 595 & 5 \\
\hline petek & 4 & 2.559 & 639,8 & 46,8 & 17,5 & 685 & 576 & 3 \\
\hline sobota & 5 & 219 & 43,8 & 15,1 & 1,5 & 60 & 21 & 2 \\
\hline nedelja & 5 & 136 & 27,2 & 12,7 & 0,9 & 39 & 12 & 1 \\
\hline Skupaj & 30 & 14.635 & 487,8 & 333,2 & 100 & 839 & 12 & $/$ \\
\hline
\end{tabular}

Legenda: $n$ - število, $\bar{x}$ - povprečje, $s$ - standardni odklon, \% - delež, maks - maksimum, min minimum, $R$-absolutni rang

V 20 delovnih dneh je bilo največ zapisov kreiranih v štirih torkih, tj. 3.098 zapisov (21,7 \%), povprečno 774,5 zapisov $(s=33,4)$ vsak torek, povprečje prirasta v COBIB.SI v delovnih dneh septembra pa je $714(s=88,5)$. Sobote in nedelje v septembru $(n=10)$ so prirastu dodale 355 zapisov (2,4 \%).

\subsubsection{Oktober}

Oktober 2018 je z 10,5 \% letnega prirasta ( $n=17.716$ ) na prvem mestu po številu kreiranih zapisov. Katalogizatorji so v 22 delovnih dnevih kreirali 17.332 zapisov $(\bar{x}=787,8, s=81,8)$. V oktobru je bilo 5 ponedeljkov in 5 torkov. Zapisi, kreirani $v$ teh dneh, skupaj predstavljajo $45,7 \%$ kreiranih bibliografskih zapisov. Največ zapisov na posamezen dan je bilo kreiranih v četrtek, 25. 10. 2018, in sicer 914, sledita ponedeljek, 22. 10. 2018, z 897 in torek, 23. 10. 2018, 
z 895 bibliografskimi zapisi. $\vee 9$ dela prostih dnevih je bilo kreiranih 384 zapisov $(\bar{x}=42,7, s=$ $12,3)$, kar znaša $2,1 \%$ mesečnega prirasta (slika 11 ).

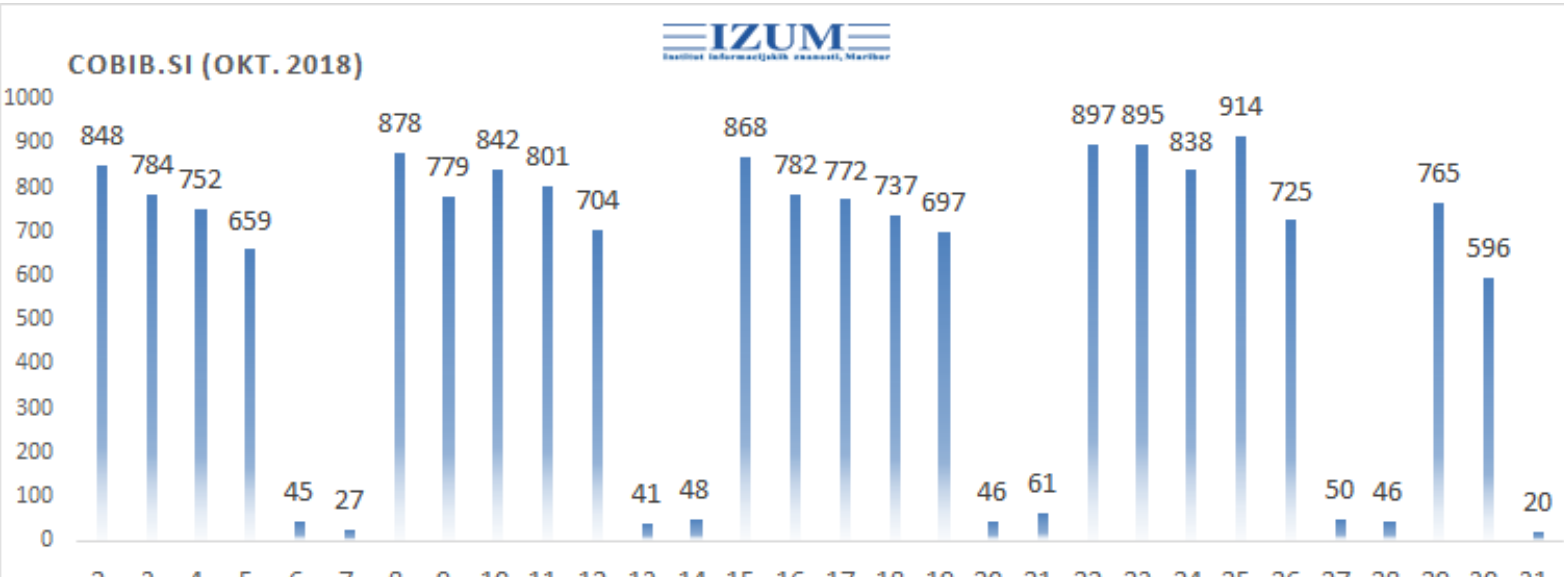

Slika 11: Število bibliografskih zapisov, kreiranih oktobra 2018 (podatki na dan 5. 11. 2018)

Podrobnosti prirasta v mesecu (zajeti so vsi dnevi) so predstavljene v tabeli 12 , podatki v koloni Dan so razvrščeni glede na absolutni rang, ki, z izjemo sobote in praznika, sledi zaporedju dni v tednu.

Tabela 12: Bibliografski zapisi, kreirani oktobra 2018

\begin{tabular}{lllllllll}
\hline Dan & $\begin{array}{l}\text { Dni v } \\
\text { mescu }(\boldsymbol{n})\end{array}$ & $\begin{array}{l}\text { Zapisi } \\
(\boldsymbol{n})\end{array}$ & $\begin{array}{l}\text { Zapisi } \\
(\overline{\boldsymbol{x}})\end{array}$ & $\begin{array}{l}\text { Zapisi } \\
(\boldsymbol{s})\end{array}$ & $\begin{array}{l}\text { Zapisi } \\
(\boldsymbol{\%})\end{array}$ & $\begin{array}{l}\text { Zapisi } \\
(\boldsymbol{m a k s})\end{array}$ & $\begin{array}{l}\text { Zapisi } \\
(\boldsymbol{m i n})\end{array}$ & $\boldsymbol{R}$ \\
\hline ponedeljek & 5 & 4.207 & 841,4 & 56,5 & 23,7 & 897 & 765 & 7 \\
\hline torek & 5 & 3.900 & 780,0 & 113,7 & 22,0 & 895 & 596 & 6 \\
\hline sreda & 4 & 3.236 & 809,0 & 36,2 & 18,3 & 842 & 772 & 5 \\
\hline četrtek & 4 & 3.204 & 801,0 & 80,1 & 18,1 & 914 & 737 & 4 \\
\hline petek & 4 & 2.785 & 696,3 & 27,5 & 15,7 & 725 & 659 & 3 \\
\hline nedelja & 4 & 182 & 45,5 & 14,0 & 1,0 & 61 & 27 & 2 \\
\hline sobota & 4 & 182 & 45,5 & 3,7 & 1,0 & 50 & 41 & 2 \\
\hline praznik & 1 & 20 & 20,0 & $/$ & 0,1 & 20 & 20 & 1 \\
\hline Skupaj & 31 & 17.716 & 571,5 & 350,6 & 100 & 914 & 20 & $/$ \\
\hline
\end{tabular}

Legenda: $n$ - število, $\bar{x}$ - povprečje, $s$ - standardni odklon, \% - delež, maks - maksimum, min minimum, $R$-absolutni rang

\subsubsection{November}

Sreda, 7. 11. 2018, je dan, ko je bilo v novembru kreiranih največ bibliografskih zapisov ( $n=$ 949), sledita ji četrtek, 8. 11. 2018, z 920 in torek, 13. 11. 2018, z 900 kreiranimi bibliografskimi zapisi. Glede na dan v tednu so bili četrtki (skupno z 19,8 \%) najbolj produktivni dnevi za kreiranje zapisov na mesečni ravni (slika 12). Enako je bilo tudi leto prej. November je s 17.041 $(10,1 \%)$ kreiranimi bibliografskimi zapisi na 2 . mestu po številu kreiranih zapisov na letni ravni. 


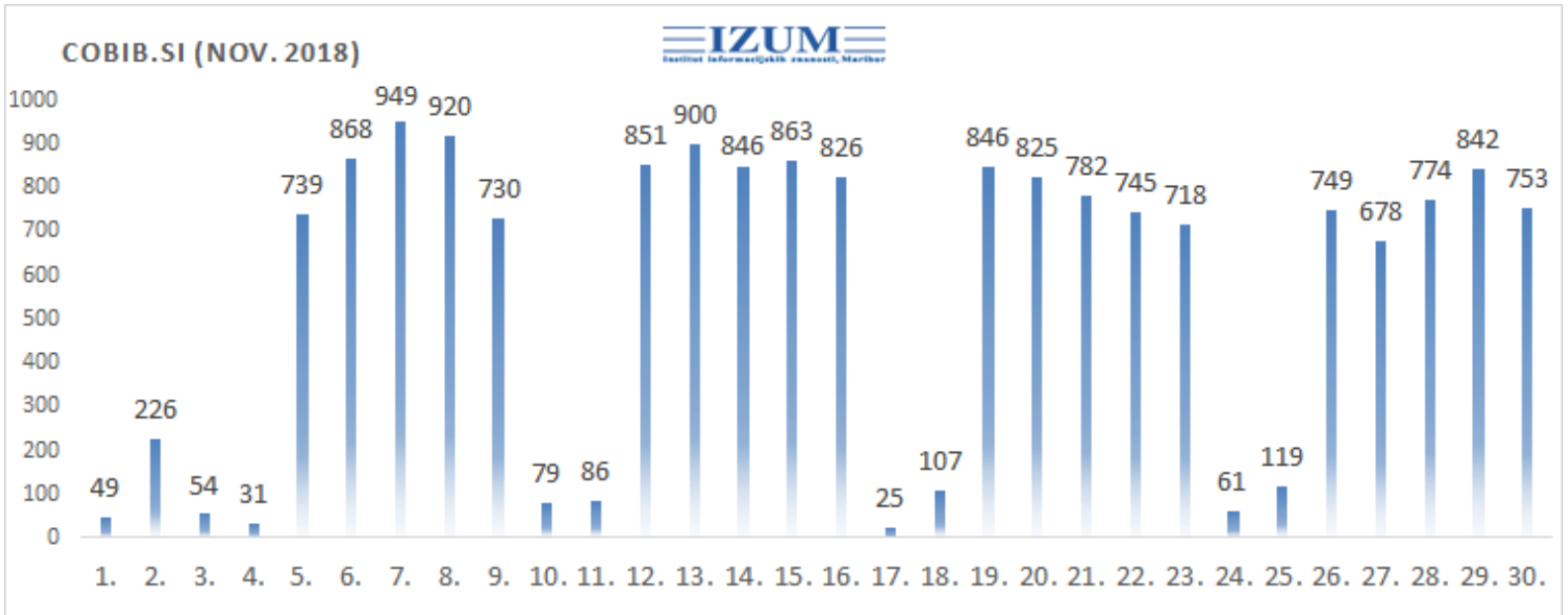

Slika 12: Število bibliografskih zapisov, kreiranih novembra 2018 (podatki na dan 3. 12. 2018)

V štirih delovnih četrtkih so katalogizatorji kreirali 3.370 zapisov, kar predstavlja 20,5\% mesečnega prirasta; sledijo 4 delovne srede z 20,4 \% ali 3.351 zapisi ter 4 delovni torki z 19,9\% ali 3.271 zapisi, če upoštevamo samo delovne dni. $V$ delovnih dneh se je COBIB.SI povečal za 16.430 novih zapisov, povprečno za 782,4 na dan $(s=146,1)$. $\vee 9$ dela prostih dneh se je COBIB.SI povečal za 611 zapisov $(\bar{x}=67,9, s=32,4)$, kar je v enem mesecu na letni ravni. Zapisi, kreirani ob vikendih in na praznični dan, tako predstavljajo $3,6 \%$ mesečnega prirasta.

Mesečni prirast je s podrobnimi podatki predstavljen v tabeli 13.

Tabela 13: Bibliografski zapisi, kreirani novembra 2018

\begin{tabular}{lllllllll}
\hline Dan & $\begin{array}{l}\text { Dni v } \\
\text { mescu }(\boldsymbol{n})\end{array}$ & $\begin{array}{l}\text { Zapisi } \\
(\boldsymbol{n})\end{array}$ & $\begin{array}{l}\text { Zapisi } \\
(\overline{\boldsymbol{x}})\end{array}$ & $\begin{array}{l}\text { Zapisi } \\
(\boldsymbol{s})\end{array}$ & $\begin{array}{l}\text { Zapisi } \\
(\%)\end{array}$ & $\begin{array}{l}\text { Zapisi } \\
(\boldsymbol{m a k s})\end{array}$ & $\begin{array}{l}\text { Zapisi } \\
(\boldsymbol{m i n})\end{array}$ & $\boldsymbol{R}$ \\
\hline ponedeljek & 4 & 3.185 & 796,3 & 60,5 & 18,7 & 851 & 739 & 4 \\
\hline torek & 4 & 3.271 & 817,8 & 98,1 & 19,2 & 900 & 678 & 6 \\
\hline sreda & 4 & 3.351 & 837,8 & 80,9 & 19,7 & 949 & 774 & 7 \\
\hline četrtek & 4 & 3.370 & 842,5 & 72,9 & 19,8 & 920 & 745 & 8 \\
\hline petek & 5 & 3.253 & 650,6 & 241,0 & 19,1 & 826 & 226 & 5 \\
\hline sobota & 4 & 219 & 54,8 & 22,5 & 1,3 & 79 & 25 & 2 \\
\hline nedelja & 4 & 343 & 85,8 & 39,0 & 2,0 & 119 & 31 & 3 \\
\hline praznik & 1 & 49 & 49,0 & $/$ & 0,3 & 49 & 49 & 1 \\
\hline Skupaj & 30 & 17.041 & 568 & 354,9 & 100 & 949 & 25 & $/$ \\
\hline
\end{tabular}

Legenda: $n$ - število, $\bar{x}$ - povprečje, $s$ - standardni odklon, \% - delež, maks - maksimum, min minimum, $R$-absolutni rang

\subsubsection{December}

December 2018 je s 15.008 (8,9 \%) kreiranimi zapisi uvrščen na tretje mesto po številu kreiranih zapisov na letni ravni. Na sliki 13 je vidno, da je bilo največ zapisov kreiranih v četrtek, 6. 12. 2018, in sicer 1.060. Tako je bila takrat prvič v letu 2018 presežena meja 1.000 kreiranih zapisov na dan. Tudi sicer so bili katalogizatorji v decembru zelo učinkoviti, saj so po številu zapisov, kreiranih na posamezen dan, kar 4 dnevi (6., 5., 11. in 12. 12.) na prvem mestu po številu kreiranih zapisov na letni ravni. 


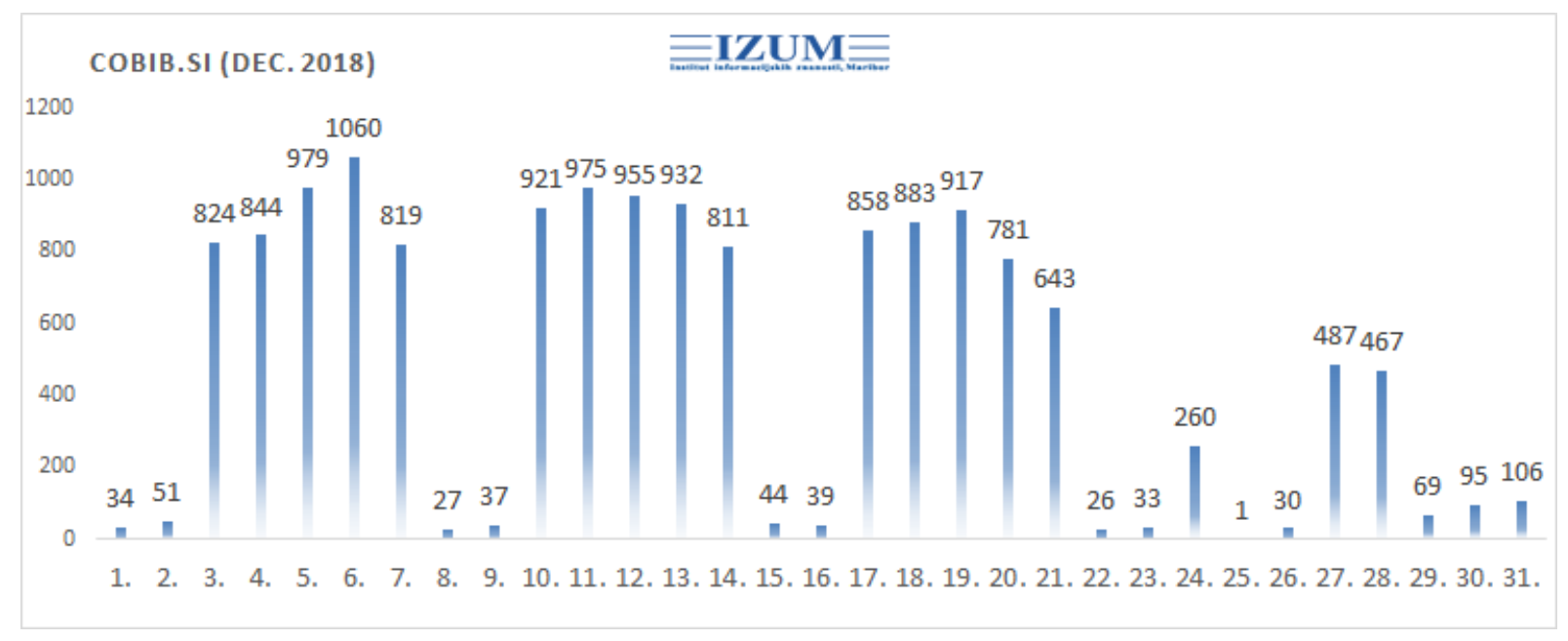

Slika 13: Število bibliografskih zapisov, kreiranih decembra 2018 (podatki na dan 3. 1. 2019)

Decembra so bili 4 četrtki najbolj produktivni dnevi glede na skupno število kreiranih zapisov ( $n=3.260$ ali $21,7 \%)$, sledi 5 ponedeljkov z 19,8\% $(n=2.969)$. Podrobnosti mesečnega prirasta so predstavljene $v$ tabeli 14 (podatki so razvrščeni glede na rang).

Tabela 14: Bibliografski zapisi, kreirani decembra 2018

\begin{tabular}{lllllllll}
\hline Dan & $\begin{array}{l}\text { Dni v } \\
\text { mescu }(\boldsymbol{n})\end{array}$ & $\begin{array}{l}\text { Zapisi } \\
(\boldsymbol{n})\end{array}$ & $\begin{array}{l}\text { Zapisi } \\
(\overline{\boldsymbol{x}})\end{array}$ & $\begin{array}{l}\text { Zapisi } \\
(\boldsymbol{s})\end{array}$ & $\begin{array}{l}\text { Zapisi } \\
(\%)\end{array}$ & $\begin{array}{l}\text { Zapisi } \\
(\boldsymbol{m a k s})\end{array}$ & $\begin{array}{l}\text { Zapisi } \\
(\boldsymbol{m i n})\end{array}$ & $\boldsymbol{R}$ \\
\hline četrtek & 4 & 3.260 & 815,0 & 246,6 & 21,7 & 1.060 & 487 & 8 \\
\hline ponedeljek & 5 & 2.969 & 593,8 & 380,5 & 19,8 & 921 & 106 & 7 \\
\hline sreda & 3 & 2.851 & 950,3 & 31,3 & 19,0 & 979 & 917 & 6 \\
\hline petek & 4 & 2.740 & 685,0 & 166,5 & 18,3 & 819 & 467 & 5 \\
\hline torek & 3 & 2.702 & 900,7 & 67,3 & 18,0 & 975 & 844 & 4 \\
\hline nedelja & 5 & 255 & 51,0 & 25,5 & 1,7 & 95 & 33 & 3 \\
\hline sobota & 5 & 200 & 40,0 & 17,7 & 1,3 & 69 & 26 & 2 \\
\hline praznik & 2 & 31 & 15,5 & 20,5 & 0,2 & 30 & 1 & 1 \\
\hline Skupaj & 31 & 15.008 & 484,1 & 410,5 & 100 & 1.060 & 1 & $/$ \\
\hline
\end{tabular}

Legenda: $n$ - število, $\bar{x}$ - povprečje, s - standardni odklon, \% - delež, maks - maksimum, min minimum, $R$-absolutni rang

\section{Analiza prirasta normativnih zapisov}

Vzajemna katalogizacija poteka z normativno kontrolo, kar pomeni, da katalogizatorji pri katalogizaciji z normativno kontrolo osebnih imen avtorjev bibliografske zapise povezujejo z normativnimi zapisi. Če npr. normativni zapis za osebno ime avtorja v bazi CONOR.SI že obstaja, ga povežejo; če ne, kreirajo nov normativni zapis. Za katalogizatorje to pomeni dodatno in zahtevno nalogo, saj morajo biti podatki o avtorjih pravilni in natančni, ob tem pa morajo ločevati med morebitnimi soimenjaki in preprečevati pojav podvojenih zapisov za istega avtorja. Zaradi zahtevnosti in pomembnosti omenjenega dela katalogizatorjev vključujemo kumulativne podatke o kreiranih normativnih zapisih po mesecih leta 2018 (tabela 15). V normativni bazi podatkov CONOR.SI je bilo v letu 2018 kreiranih 58.139 novih zapisov, od tega jih je bilo iz baze LCNAF (Library of Congress Name Authority File) prevzetih 
9,6 \% ( $n=5.577)$. Pri kreiranju zapisov v normativni bazi je sodelovalo 244 knjižnic (IZUM, 2019; Normativna baza podatkov CONOR.SI, 2019).

Tabela 15: Normativni zapisi v bazi CONOR.SI v letu 2018

\begin{tabular}{lll}
\hline Mesec & Zapisi, kreirani v CONOR.SI $(\boldsymbol{n})$ & Zapisi, prevzeti iz LCNAF ( $\boldsymbol{n})$ \\
\hline januar & 4.786 & 539 \\
\hline februar & 3.963 & 454 \\
\hline marec & 4.991 & 450 \\
\hline april & 4.205 & 441 \\
\hline maj & 4.460 & 495 \\
\hline junij & 4.169 & 436 \\
\hline julij & 4.742 & 412 \\
\hline avgust & 3.826 & 339 \\
\hline september & 5.594 & 340 \\
\hline oktober & 5.875 & 487 \\
\hline november & 6.348 & 625 \\
\hline december & 5.180 & 559 \\
\hline Skupaj & 58.139 & 5.577 \\
\hline
\end{tabular}

Legenda: $n$-število; CONOR.SI - normativna datoteka osebnih in korporativnih imen; LCNAF-Library of Congress Name Authority File

\section{Diskusija}

Večletni trend prirasta bibliografskih zapisov se nadaljuje v leto 2018 in nakazuje na sezonske variacije prirasta bibliografskih zapisov (slika 1). Po podatkih $\vee$ Centralnem registru uporabniških imen (16. 7. 2019) ima v Sloveniji 652 oseb aktivno uporabniško ime in dovoljenje za vzajemno katalogizacijo monografskih publikacij. Med njimi jih ima 71,3 \% ( $n=465)$ eno uporabniško ime, $17,2 \%(n=112)$ dve uporabniški imeni, $11,5 \%(n=75)$ pa tri ali več. Več uporabniških imen kaže na to, da nekateri knjižničarji delujejo tudi zunaj svoje matične knjižnice oz. sodelujejo $v$ več organizacijah. $\mathrm{Na}$ to nakazuje delež $(2,5 \%)$ letnega prirasta bibliografskih podatkov ob praznikih in dela prostih dneh. Prav tako ni enega dneva v letu, ko ne bi bil kreiran vsaj en bibliografski zapis.

Letni prirast, razdeljen na kvartale, pokaže, da je bil skupni prirast najvišji v zadnjem kvartalu $(29,4 \%)$, sledijo prvi $(23,9 \%)$, tretji $(23,8 \%)$ in drugi $(22,9 \%)$. V prvem in drugem kvartalu je bil najbolj produktiven dan sreda; $v$ tretjem kvartalu je to torek, $v$ četrtem kvartalu pa ponedeljek. Največ zapisov glede na dan v tednu je bilo kreiranih ob torkih (21\%), sledijo sreda $(20,4 \%)$, četrtek (20,3\%), ponedeljek (19,9\%) in petek (18,5\%). Glede na posamezni mesec je torek najbolj produktiven dan $v$ februarju, juliju, avgustu in septembru; sreda $v$ januarju in aprilu; četrtek je vodilni dan po številu kreiranih bibliografskih zapisov $v$ marcu, maju, novembru in decembru. Junija je bil najbolj produktiven petek, oktobra pa ponedeljek.

V juniju je bil vodilni dan po številu kreiranih zapisov petek, čeprav je to na letni ravni dan z najmanj kreiranimi zapisi, a ker je bilo junija 5 petkov, je to razumljiva posledica (tabela 8). Pregled prirasta po mesecih kaže, da je v 2018 februar najnižje na lestvici letnega prirasta 
(7 \%). Pričakovali smo, da bo to avgust (7,1\%), kar je sicer večletni trend in ga pripisujemo sezonski komponenti, saj je to mesec letnih dopustov (slika 1). Kaže, da je tudi februar pod vplivom sezonske komponente, saj so februarja šolske počitnice, in predvidevamo, da je posledično v delovnem okolju prisotnih manj katalogizatorjev.

Vse to dokazuje, kako živa je bibliografsko-kataložna baza COBIB.SI, saj se število kreiranih zapisov ves čas spreminja. Pri interpretaciji podatkov ne smemo pozabiti, da so bili podatki zbrani tekom leta 2018, zato se stanje bibliografsko-kataložne baze in absolutne številke kreiranih zapisov (lahko) razlikujejo od trenutnega števila kreiranih zapisov po posameznem dnevu in/ali mesecu (npr. izbrisani podvojeni zapisi, prav tako smo iz prikaza izvzeli bibliografske zapise, ki so bili vključeni v COBIB.SI zaradi ažuriranja baze ELINKS.SI, in zapise iz lokalnih baz podatkov, ki se shranjujejo na vzajemni nivo). Izpostaviti moramo tudi kakovost bibliografskih in normativnih zapisov. Nikakor ne smemo pozabiti, kako pomembno je kakovostno delo katalogizatorjev in kako velik vpliv ima njihovo delo na več storitev, ki temeljijo na bibliografskih zapisih (npr. izposoja po knjižnicah, vodenje osebnih bibliografij, evalvacija znanstvenoraziskovalnega dela, knjižnično nadomestilo itd.) in normativnih zapisih (npr. normativni zapisi za osebna imena avtorjev baze podatkov CONOR.SI so preneseni $v$ mednarodni sistem Virtual International Authority File (VIAF) in so dostopni širši svetovni javnosti). $V$ vseh pogledih ima kakovostno delo katalogizatorjev pomembno vlogo $v$ sistemu COBISS. Z izvajanjem aktivnosti, ki so del sistema zagotavljanja kakovosti bibliografskih in normativnih zapisov v COBIB.SI (Dornik et al., 2017), želimo doprinesti k čim višji kakovosti podatkov v COBIB.SI.

\section{Zaključek}

Razvoj informacijske družbe temelji na informacijah in znanju, ki je zabeleženo $v$ bazah COBISS.net, hkrati pa so ti podatki tudi odraz te družbe. Poudariti želimo, da ima katalogizatorjevo delo velik vpliv na uporabnost podatkov, dostopnih v COBISS.SI. Ne moremo mimo dejstva, da smo v lokalnih bazah COBISS.SI sredi leta 2018 zabeležili 15-milijonti zapis. Menimo, da tudi to kaže na izredno pomembnost te baze za slovenski prostor.

$\mathrm{Na}$ osnovi analiz prirasta in spremljanja trendov bomo tudi $v$ prihodnje lažje načrtovali morebitne posege $\mathrm{v}$ baze podatkov, izvajali dodatne analize podatkov, načrtovali nove aktivnosti pri dopolnitvah programske opreme ipd. Želimo uvesti celovitejši pristop k zagotavljanju kakovosti podatkov ter v izvajanje aktivnosti vključiti katalogizatorje ter izhajati iz njihovih potreb in načinov dela.

\section{Zahvala}

Zahvala je namenjena vsem katalogizatorjem, ki s svojim strokovnim in vestnim delom prispevajo svoj del $v$ mozaik kakovostnih podatkov $v$ bazah $v$ sistemu COBISS. Brez katalogizatorjev tudi te analize prirasta v letu 2018 ne bi bilo. Hvala vsem in vsakemu posebej.

\section{Reference}

Bibliografske baze podatkov in podatki o zalogi: polnopravni člani sistema COBISS.SI in njihovo sodelovanje $v$ sistemu vzajemne katalogizacije, 2019. Dostopno na:

https://www.cobiss.si/kazalci/doc/STAT PRIRAST 2018 SI 1.pdf [26. 3. 2019]. 
COBISS.net: mreža knjižničnih informacijskih sistemov in informacijskih sistemov o raziskovalni dejavnosti, 2019. Dostopno na: https://www.cobiss.net/si/ [15. 3. 2019].

COBISS.net $v$ številkah, 2019. Dostopno na:

https://www.cobiss.net/doc/Stat kazalci 2018.pdf [11. 6. 2019].

COBISS3 - Knjižnice, 2019. Dostopno na: http://home.izum.si/cobiss/cobiss3/ [22. 7. 2019].

Dornik, E., Badovinac, B., Kos, J. in Farkaš, B., 2017. Sistem zagotavljanja kakovosti COBIB.SI: izbrane aktivnosti za leto 2016. Knjižnica, 61(1/2), str. 191-205. Dostopno na:

https://knjiznica.zbds-zveza.si/knjiznica/article/view/6167 [17. 1. 2018].

Dovoljenja za vzajemno katalogizacijo, 2019. Dostopno na:

https://izobrazevanje.izum.si/EntryFormDesktopDefault.aspx?tabid=360\&type=licence [15. 3. 2019].

IZUM, 2019. Letno poročilo o delu IZUM za leto 2018. Maribor: Institut informacijskih znanosti. Dostopno na: https://izum.si/doc/letno-porocilo-2018.pdf [15. 3. 2019].

Normativna baza podatkov CONOR.SI, 2019. Dostopno na:

https://www.cobiss.si/kazalci/doc/STAT PRIRAST CONOR 2018 SI.pdf [19. 3. 2019].

Organizacijski model sistema COBISS, 2018. Dostopno na:

https://www.cobiss.net/si/platforma-cobiss.htm\#c2 [4. 5. 2018].

Vzajemna katalogizacija (COBISS3/Katalogizacija), 2019. Dostopno na:

https://www.cobiss.net/si/platforma-cobiss.htm\#c4 [15. 3. 2019]. 